\title{
Analytic Study of Legal Dimensions in Shell Corporations
}

\author{
Zeana Ghanim Abdijabar, College of Law, Ajman University, Ajman, United Arab Emirates, \\ z.abdijabar@ajman.ac.ae
}

\begin{abstract}
Under the temptation of personal interests, a partner might break the rules determined by law to create an appropriate environment for the commencement of a commercial activity. In order to achieve this activity, he strives to establish a commercial company that he owns by himself without having partners. By taking such action, he is violating the law, which says that a commercial company shall have at least two partners. A memorandum of association, indeed, is a contract between two persons or more who participate in an economic project. One of the main objectives of this project is to achieve profit. Partners, when signing the memorandum of association, shall provide a share of money or work, and accordingly, they share the profits or losses that result from this agreement (See Federal Commercial Transactions Law, 2015). Sometimes when the economic project is so huge and requires a large capital investment, a partner may resort to establishing a shell company as a legal entity enacted as per the procedures identified by the Commercial Companies Law. These procedures include registration, publicity, and taking one of the specified forms of a company, such as a solidarity company, a simple recommendation firm, or a private shareholding company. However, the truth of this company is completely different from the apparent situation. Indeed, the owner of this firm is only one person, and thus violating one of the essential rules of establishing a company. To avoid this problem, the owner finds an alternative within a legal framework to solve the partners' issue, which is required by the companies' law in most legislations, and that is through the establishment of a shell corporation. However, the non-deniable fact is that the reality of having partners remains imaginary. Simply because a shell company is owned only by one person. The real motivation behind the establishment of this type of company lies in a number of reasons. First, the owner is incapable of owning the business only by himself as per regulations. Secondly, the inability to obtain certain banking facilities, and finally, the owner could be a foreigner who is prohibited by national law to own a commercial enterprise alone. This trend seems to raise a number of problematic issues. For instance, one might wonder about the degree of liability of imaginary partners for the debts of the company. Another issue is the effect of the company's actions on third parties who have no idea about the reality of the company, that it is a shell corporation. This misleading situation shall indeed violate the commercial credit element.
\end{abstract}

Keywords: commercial company, the partners, owner, shell Corporation.

Received: $10.12 .2020 \quad$ Accepted: 01.01.2021 Published: 03.02.2021

\section{INTRODUCTION}

The Commercial Companies Law incorporates a legal structure, which regulates the procedures of establishment, management, membership of every company, (see Fakhri\& Aleryani, 1995) and even the possibility of their expiry if the reasons for such action are fulfilled. However, a person, whether natural or legal, often resorts to establishing a company as per the legal procedures required. Part of these procedures is to determine the type of the company whether it is a private joint stock company, a solidarity firm, or any other type. Undoubtedly, there will be no defect in all these procedures, and the company practically shall appear as a genuine one. But in reality, the owner of this company is just one person who wants to do his business under a legal guise, and that is the company in its apparent form. As for the multiplicity of partners, it is imaginary and not real, just to meet the partners' condition required by law. (see Alsharqawe, 1983). The owner selects this type of company to achieve certain objectives. One of these objectives is to obtain specific banking facilities. Another objective is to attract the public to trust the names of the "Non Real Partners" of the company. Thus, the individual business of the real owner of the shell corporation will disappear behind the legalized form of the company in question. In other words, the owner circumvents the provisions of the law and the prohibition included therein by establishing a shell company by his own capital and self-management without the participation of real partners. Meanwhile, he is under the legal protection of establishing commercial companies. (see Albaroodi, 1986).

In general, from a legal point of view, this company is legitimate, but in reality, it is a shell corporation, i.e. a fictitious one, simply because it represents an individual commercial project owned by one person only. (see Karman, 1997). A shell corporation has one problematic issue and that is the lack for multiplicity 
of partners. As we said before, it is in fact an individual commercial project. As for the partners, they are not real and their names appear in the memorandum of association just to obtain the legal form imposed by law.

\section{METHODS}

The researcher adopts a descriptive analytic method so as to describe, analyze and interpret the implications of analytic Study of Legal Dimensions in Shell Corporations.

\section{LITERATURE REVIEW}

For the purpose of covering all aspects, theoretical and practical, our research has been divided into two main parts preceded by general framework of compulsory insurance, its liability as well as legal and legitimate nature, and Implications of compulsory insurance and its civil liability.

\section{Shell Corporation}

In this part of the current research, we shall cover three main issues: definition of a shell corporation, its main features, and the differences between a shell corporation and a suspect company. As per a number of jurisprudential scholars, a shell corporation is a fictitious company, which forms an unreal interface to an activity that the owner of this firm practices, and it can be one of the forms of persons or money companies. The same group of scholars go farther in their claim positing that a shell corporation is an unapproved company, which hides an individual project. Besides, the objective of the shell corporation could be a permissible one, and therefore it becomes a legitimate route for the achievement of certain goals. Several parties who share a common interest are often behind such goals. However, and due to the lack of considering the formalism imposed by the law, the contract is considered as void. Unlike other contracts, in which interests of parties may conflict, the compatibility of the partners' interests is a main feature of a shell corporation contract. Indeed, there is only one unified goal that lies behind establishing this legal entity. Simply, it is achieving profits (see Hattab \& Farah, 2017). It is remarkable to note that man-made laws do not include any information about regulating or even referring to the subject of a shell company. Accordingly, diligence is highly required as well as hard efforts that shall be made to come up with a feasible definition for this type of company. The researcher suggests the following definition for a shell corporation:

"It is a company established as per an agreement between two or more persons, and it takes one of the forms stipulated in the Commercial Companies Law. The legislator has authorized the ownership of this company to one person or more. Management of the company's activities with all resulting efforts shall be the responsibility of the owner himself. The others are just sham partners who appear in the image to complete the legal form that the law requires."

It seems that the judiciary has settled the dispute about the sham issue in civil transactions confirming that "the contract in force between parties is the real one as per Article No 395 of the Civil Transactions Law. If this contract, i.e. the one in force, conceals another contract, which violates the law, then this one, the hidden contract, is considered as void (Dubai Court of Cassation, Technical Office, Commercial Appeals, 2015). However, it is almost inapplicable to implement this judicial viewpoint on a shell corporation already conducting its activities and dealing with the public. Being committed to the principle, which says, "The priority is for the stability in commercial dealings and for the protection of credit", nobody can deny or ignore the obligations that result from the previous situations. As for the possibility that the partner in this company could acquire the status of a merchant, it depends indeed on the type of the company established. For example, if a shell corporation takes the form of a company of persons, such as a solidarity or a simple recommendation, the partner becomes a merchant, and therefore, he shall be responsible in person for the debts of the company. Anyhow, if the shell corporation takes the form of a joint stock company, though probability is very low, the shareholder cannot acquire the status of a merchant, unless he is originally a trader (Othman, 1996).

\section{Features of a Shell Corporation}

The main characteristics of a shell corporation can be summarized as follows. A shell corporation is a commercial company established for the purpose of obtaining legitimate profits by launching a specific commercial activity, and as identified in the memorandum of association and in the contract that is registered with the concerned authorities. It has no real multiplicity of partners, though it is an essential aspect for the establishment of the company by signing a contract between two people at least, whether it takes the form of a private joint stock or a limited liability. It is remarkable to note however that the Emirati legislator, in the Federal Commercial Companies Law, has permitted the establishment of a company owned by one person no matter what form it takes. It is considerable to note that the legislations of some 
countries require the partner to have a national citizenship. Thus, there will be no possibility for foreign traders in these countries to establish a commercial company by themselves. Accordingly, foreigners' resort to establishing shell corporations with which they can obtain the authorities approvals.

Lack of intention for participation, which means that partners are not serious in establishing the company, carrying out its activities and achieving objectives as well sharing the rights and obligations that result from the company's activities. In other words, partners in a shell corporation are fake persons, i. e, their names and signatures are on the memorandum of association, but they have no actual role in the company, and thus circumventing the law (Hassan, 2019). A shell corporation has a trade name derived from the type of activities it operates, and all undertakings are signed and implemented on its behalf. The capital of the company consists of only one share provided by the owner. The other partners whose names are stated in the contract pay no shares. Dubai Court of Cassation clarifies the issue and as follows "The shares that the partners pledge to pay to the company are bogus, and the company does not convene. But if some of the shares are real and others are fake, the company then shall gather, attended only by those who have real shares, and the partner with a fake share has the right to appeal against his fake partnership in the company" (Dubai Court of Cassation, Appeal No 76, for the year 1999).

\section{Differences between a Shell Corporation \& a Suspect Company}

A shell corporation may look like an actual one, or what is usually known as the "De Facto Company". Besides, it might be similar to a "Joint Venture Company". In the forthcoming sub-sections, we shall attempt to investigate these two issues. A company is considered an actual one or a "De Facto Company" when it loses one of the nominal conditions required by law, and that is writing and announcement. Hence, we cannot regard this company as void because nullity results from losing one of the general objective conditions that are essential for establishing a company, such as, for instance, the illegality of the company's purpose. Anyhow, the problem will rise if the company starts its activity, and there is a defect in one or both of its nominal conditions, i.e. writing or announcement. In other words, it starts to take a role in economic life, and therefore becomes a creditor or a debtor. In this case, a decision to nullify the company will certainly lead to damaging the rights of customers and a disastrous breach of the commercial trust (AlQalyoubi, 2011).

In order to avoid such destructive consequences, the idea of a de facto company started to come into existence. Simply, it means that the company's invalidity has no retroactive effect, and it proceeds in action from the start until the issuance of an adjudication, which will nullify it (Sami, 2010). In conclusion, we may say that a de facto company is the firm that has started activity and then adjudicated invalid for the reasons stated above. However, this nullity does not apply to the company's actions before judgment. If the judgment of the company's invalidity is issued as per the request of others, then the nullity will be retrospective and the partners' liability towards the others will be personal and joint. If the adjudication of invalidity is made as per the request of one of the partners, the effect of nullity starts from the issuance date (Mahir, 1984). After clarifying the concept of the "De Facto Company" and comparing it with the "Shell Corporation", we notice that there are two essential differences between the two companies. They are as follows. Multiplicity of partners: while this element is available in the de facto company, the shell corporation is devoid of it. Intention of participation: the members of a de facto company have the intention to work together despite the fact that the company shall be ruled invalid in a later stage. This intention is not found in a shell corporation.

\section{Joint Venture Company}

A joint venture company is a hidden firm summoned by two persons or more who convene to divide the profits and losses that result from a particular commercial business. This business is conducted by one partner and in his name. The others are unaware of the existence of the company, having in their minds that it is just a commercial project (Atwi, 2005). This type of company does not have a legal personality because, unlike other companies, it does not follow the establishing procedures of writing and publicizing. Instead, one of the partners, often the apparent one, deals with others who have no idea about the existence of other partners, and the relationship of the company is confined only among partners. The others have no legal association with the company's business except their relation with the partner, the apparent one, whom they have signed a contract with. After that, the partners gather to calculate and share the profits and losses as per the agreement included in the memorandum of association. Most companies' laws, in fact, have taken into consideration the legislative regulations of the joint venture company. The Companies Law of the State of Bahrain, No. 28 for the year 1975 and the Commercial Companies Law of the State of Kuwait, No. 15 for the year 1960 are good examples for the issue in question.

We cannot consider a joint venture company as a shell corporation for the following reasons. Unlike a shell corporation, a joint venture company includes two or more partners who share confidence and 
knowledge for the purpose of establishing an economic project in order to achieve certain profits. Besides, it has no legal personality or independent financial liability due to the lack of writing and publicizing procedures. A joint venture company has no commercial name, home or nationality, whereas, a shell corporation has all these features.

\section{Implications of a Shell Corporation Activity}

If a shell corporation starts a commercial activity that leads to a set of rights and obligations towards a third party, it is necessary to arrange legal effects on that activity. These legal effects will take the form of specific relationships resulting from the activity in question. The forthcoming subsections will investigate these issues. An imaginary partner is the person who agrees that his name appears in a memorandum of association to establish a company as per the provisions of law with no intention for participation, and without sharing in the capital. Hence, he shall not receive, now or later, any profits from this company. Meanwhile, this imaginary partner will not bear any losses that the company might suffer from.

Article No. 12 of the UAE Commercial Transactions Law, No. 18 for the year 1993 states that, "Whoever informs the public, by using any means, about a location he shall utilize for business, he therefore will be treated as a trader even if trade is not his usual craft." Similarly, an imaginary partner shall acquire the status of a trader if he appears to others as a partner in the commercial company. Subsequently, he shall bear all his obligations, and even to be subject to bankruptcy until proven otherwise. In other words, an imaginary partner cannot avoid or escape his responsibilities towards the law and towards the others who have dealt with the company and its members, having in their minds that they are dealing with real partners. It is necessary to distinguish between two types of imaginary partners. The first knows everything about the establishment of the shell corporation without having an objection to joining it, though just nominally. He shall nevertheless bear responsibility towards the others and towards the company as a legal person. As for the second type of imaginary partners, this one is unaware of the establishment of the shell corporation, and the owner has illegally enlisted his name without his knowledge, though such case is very rare. This fictitious partner has the right to object to this illegal situation by all possible means. Accordingly, he shall not bear any responsibility for the activities managed by the company.

\section{Legal Position of Shell Corporation's Sole Owner}

The sole owner of a shell corporation often resorts to circumventing the law by adopting an approach based on legal texts to establish a commercial company with a certain form. This circumvent is similar to a curtain, which hides facts totally different from the apparent ones. It is indeed not a company at all, but an individual enterprise owned by one person who is responsible for all obligations resulting from the corporation's activities. The real owner of a shell corporation is often himself the manager, and he fully bears all the effects resulting from exploiting the project as his name appears in the contract of the corporation. Sometimes, his name also is shown in the address of the firm if it is one of the companies of persons. Besides, as a sole owner and a manager, he alone manages the project and controls all facilities. As a result, the owner of a shell corporation is responsible for all the companies' obligations, exactly similar to an individual merchant who owns a supermarket (Hassan, 2019). Article No. 11 of the UAE Commercial Transactions Law considers a situation similar to that of the shell corporation. It states that, "Anyone, who uses his name in business and having all requirements for qualification, is considered a trader if he adopts business as his craft."

\section{Shell Corporations in Face of Others}

The "others" here refers to anyone who deals with the company, enters into negotiation, and comes up with a contract related to the activities of the company, and accordingly becomes a creditor or a debtor. It is confirmed that a creditor or a debtor to the company deals exclusively with the manager of the company or with a representative, and in both cases, this person is, or appears to be, responsible for the management of the shell corporation. It is necessary therefore to differentiate between two types of "others" or what we may call "a |third party". The first is a bona fide third party who signs a contract with the shell company without knowing that it is just a fake interface for an individual commercial project. The owner of this project is the manager himself, and there are no partners or shareholders. As for the second type, those with bad intention, they already know everything about the reality of the company.

If the creditor to a shell corporation is a bona fide third party, and this is the prevailing assumption, the manager, i.e. the owner of the project, is responsible for this debt, and he is committed to fulfill all his obligations towards the creditor. In this case, a shell corporation cannot be considered as void since this will lead to the loss of the others' rights despite dealing with it as a real company. Besides, the main target in any business transaction is to protect the apparent situation. However, a lawsuit against the owner of the shell corporation, in case of not implementing his obligations towards a bona fide third party, has 
indeed two faces. One face represents a lawsuit against the company as a legal person independent of the owner. The second face reflects a lawsuit against the owner himself as the shell company is nothing but an individual project. In fact, the responsibility of the owner of the shell corporation before bona fide third parties is an unlimited personal liability. All the money of this owner is a guarantor for payment of the debts in question, including the assets of the company as well as any other money in his possession. The failure to recognize bona fide third parties' rights will bring serious harm to these parties, and definitely will lead to destroying confidence in commercial companies.

\begin{abstract}
ANALYSIS
The legislator has authorized the ownership of this company to one person or more. Management of the company's activities with all resulting efforts shall be the responsibility of the owner himself. However, it is almost inapplicable to implement this judicial viewpoint on a shell corporation already conducting its activities and dealing with the public. we notice that there are two essential differences between the two companies. They are as follows. Multiplicity of partners: while this element is available in the de facto company, the shell corporation is devoid of it. Intention of participation: the members of a de facto company have the intention to work together despite the fact that the company shall be ruled invalid in a later stage. This intention is not found in a shell corporation. After that, the partners gather to calculate and share the profits and losses as per the agreement included in the memorandum of association. In conclusion, we may say that if a person, whether an individual or a company, practices business regularly and professionally for the purpose of earning their living (Al-Bendari, 2010), he is then a trader and he is in charge of all the consequences resulting from this legal situation. He cannot object or protest against this situation because the contract as well as the real activity, i.e. the hidden and the apparent faces of the company, indicate and confirm that he is the absolute owner of the corporation.

On the other hand, if the third party has contracted with the shell corporation and they know that it is a false company, and it is no more than just a cover for an individual commercial project, the company, accordingly is considered as void. In this case, the third party, creditors or debtors, have no option but to resort to a two-party debt relationship to solve all the pending issues between them. Moreover, anyone who has been impaired by a shell corporation, in one way or another, has the right to demand for feasible compensation. It should be noted that the Commercial Companies Law does not include a text that regulates the issues of the aforementioned company. Instead, the general rules of the Civil Transactions Law are used as a reference when considering any issue concerning the shell corporation, specifically those of mockery. The following text confirms that, "If a fake contract has been concluded, the creditors of the contractors and their successors whenever they are with good intention, they shall adhere to the fake contract as well as the hidden one, and they should prove by all means that the contract which brought them damage is a fake one. If the interests of concerned parties contradict, that some comply with the apparent contract, and others adhere to the hidden one, priority goes for those whose interests conform to the apparent one."
\end{abstract}

\title{
DISCUSSION and CONCLUSIONS
}

We may summarize our conclusions as follows. A shell corporation is defined as an agreement between two persons or more to establish an imaginary company of any sort for the purpose of practicing a specific commercial activity. The owner of this fake company in reality is one person only, and in this, the company breaches the requirement of multiple members. A shell corporation is different from other types of commercial companies, such as de facto company, which is deficient in one of the nominal conditions required by law, and that is writing or publicizing. It also differs from a joint venture company, which does not appear to the public as a company. A shell corporation shares several features with other commercial companies. Similar to other firms, it is a commercial company established with the aim of making profit. It is featured with a no-intention for participation, and the multiplicity of partners is a fake matter. Moreover, the shares in this company are fictitious. Fictitious partners bear responsibility with the owner of the project towards bona fide third parties as long as they become aware that their membership is incorporated in this shell company. Whereas the real owner of this project is explicitly responsible for the obligations of the company towards the others.

We recommend that legislators specialized in the field of commercial companies shall include a text in the Federal Commercial Companies Law stating that, "Any person who becomes a member of a shell corporation, and he is aware of this fake membership, shall be punished either by paying a fine of not less than 10,000 Dirham, or a one-year imprisonment." 


\section{REFERENCES}

Al-Bendari, Mustafa (2010). Principles of Commercial Transactions Law for the UAE State. Sharjah: AlJami'a Bookshop. Second Edition.

Albaroodi, Ali (1986). Commercial Law, Knowledge Establishment.

Alsharqawe, Mahmood Sameer, (1983) Commercial Law, Dar Al-Nahdha Al-Arabia.

Aleryani, Farid \& Fakhri Refit,) 1995(. Al Wages in Commercial Companies, Dar Al Nahdha Al Arabiya.

Al-Qalyoubi, Samiha (2011). Commercial Companies. Dar Al-Nahdha Al-Arabia. Fifth Edition.

Atwi, Fawzi (2005). Commercial Companies in Man-Made Laws \& Islamic Law. Al-Halabi Legal Publications. First Edition.

Hassan, Suzan Ali (2019). Commercial Companies. Dar Al-Nahdha Al-Arabia.

Hattab, Rasha Muhammad Tayseer \& Farah, Ahmed Qasim (2017). Commercial Companies. United Arab Emirates, University of Sharjah.

Karman, Abdu AL Rahman Al Sayed, (1997), Commercial Companies, Egypt.

Mahir, Waleed Ali (2011). Provisions of the Commercial Companies in the Federal Emirati Law No. 08 for the Year 1984. Al-Afaq Al-Mushriqa. First Edition.

Othman, Abdul Hakim Muhammad (1996). Commercial Companies. Al-Bayan Printing Press.

Sami, Fawzi Muhammad (2010). Commercial Companies in the Law of the UAE State. Sharjah: Al-Jami'a Bookshop. Second Edition. 